\title{
Distribution of Intertidal Macrobenthos in 1993 around Hatakejima Island, Central Japan, Compared with 1969 and 1983-84
}

\author{
Shun-ichi Ohgaki ${ }^{1)}$, Ryohei Yamanishi ${ }^{2)}$ \\ Yasunobu Nabeshima ${ }^{3)}$ and Keiji Wada ${ }^{4)}$ \\ 2) Osaka Museum of Natural History, \\ ${ }^{3)}$ Osaka Prefectural Fisheries Experimental Station, \\ 4) Department of Biological Science, Faculty of Science, Nara Women's University
}

\begin{abstract}
The intertidal biota of Hatakejima Island in Tanabe Bay, central Japan, was investigated in May, 1993. A survey of selected animal species around the entire coast of the island revealed different patterns of distribution in relation to wave exposure and substratum type. Comparison between the present data and those obtained in 1983 shows that several species obviously extended or contracted their distribution ranges around the island. In the survey of a selected area on the south coast, 173 macro-benthic species including 112 animal and 61 plant species were recorded. Mollusca and Crustacea were dominant among the animals, and Rhodophyta among the plants, in terms of number of species. Comparison between the present data and those obtained in 1969 and 1984 on the south coast reveals that the total number of animal species and their distribution ranges decreased from 1969 to 1984 and increased from 1984 to 1993 . The species with a southern geographical distribution $\left(<35^{\circ} \mathrm{N}\right)$ contracted and the indicator species of eutrophic water expanded their ranges from 1969 to 1984, and the reverse changes occurred from 1984 to 1993. Photographs show drastic changes in the shore scene: obvious sedimentation in 1984 and alternation of the dominant sessile bivalves between 1969 and 1993. The fluctuation in abundance of the species with a southern geographical distribution paralleled changes in the water temperature, and the fluctuation in abundance of the indicator species of eutrophic water paralleled changes in the indices of nutrient level. An influence of these environmental factors on the faunal changes of the intertidal Hatakejima Island during the last 25 years is inferred.
\end{abstract}

Key words: intertidal fauna, Hatakejima Island, faunal change, temperature, eutrophication

\section{INTRODUCTION}

Long-term ecological studies of marine benthic communities have been undertaken, for exam-

Received September 30, 1996 : Accepted July 25, 1997 ple, on coral reefs (Dahl \& Lamberts 1977; Davis 1982; Done 1992) and concerning subtidal soft-bottom benthos (Pearson et al. 1985; Josefson 1990; etc.). However, information on rocky-shore communities is still scarce, although several studies have followed the population fluctuations of individual species for 
more than a decade (Wilson 1971; Pearse \& Hines 1987; Ohgaki \& Tanase 1987).

It has been noted that the rocky-shore biota of Hatakejima Island in Tanabe Bay, central Japan, have experienced marked changes in the last ca. 30 years; many intertidal species have declined and a few species have increased or exhibited population outbreaks. Water pollution and temperature conditions in Tanabe Bay have been suggested as causes of such changes, based mostly on qualitative information (Ohgaki 1989). On the other hand, quantitative monitoring on Hatakejima Island has been carried out sporadically since the late 1960s, including surveys of the intertidal fauna and flora on the south coast in 1969 and 1984 (Ohgaki 1984) and of the distribution of selected animal species around the entire coast in 1983 (Ohgaki et al. 1985).

In 1993 we resurveyed the fauna and flora on the south coast of the island as well as the dis- tribution of selected animals around the entire coast. In this report, the results are presented and compared with the previous data. Possible factors for the changes detected in species composition are explored with reference to oceanographical data from Tanabe Bay.

\section{METHODS}

\section{Entire coast survey}

Hatakejima Island $\left(33^{\circ} 42^{\prime} \mathrm{N}, 135^{\circ} 22^{\prime} \mathrm{E}\right)$ is situated in Tanabe Bay in the southwestern part of the Kii Peninsula, Japan (Fig. 1a). Its west and north coasts face the mouth of the bay, which opens to the Pacific Ocean, and they are exposed to active wave action. The east and south coasts face the innermost part of the bay and are comparatively sheltered. The intertidal zone of the island covers 6.0 ha and comprises various kinds of substratum: rocky shore,

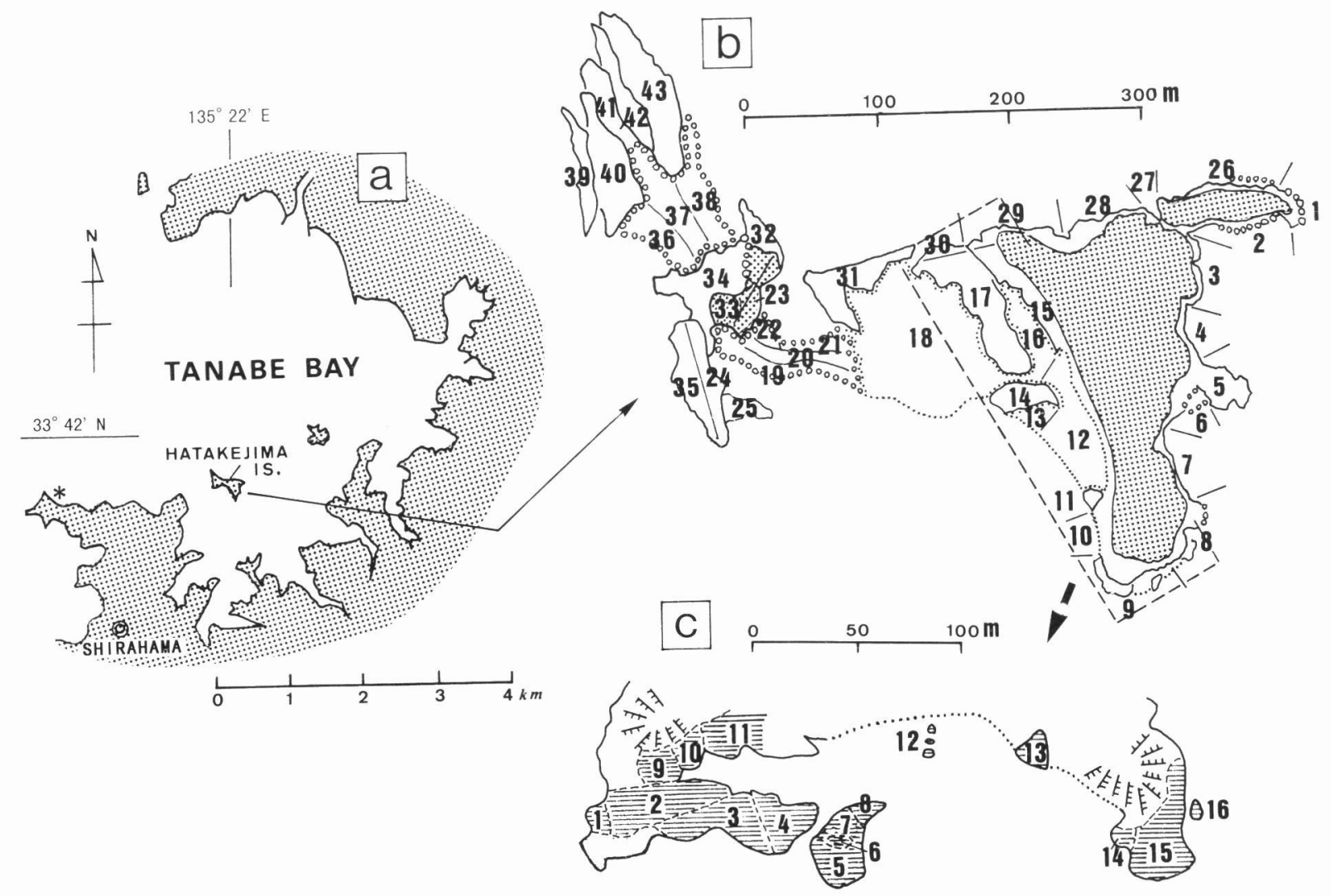

Fig. 1. Study sites. In "a”, points for measuring water temperature (asterisk) and air temperature (double circles) are shown. In "b", areas surrounded by solid lines are rocky shores, by small circles boulder beaches, and by dotted lines sandy beaches or sand-mud flats. The shaded area is land. Hatched parts in " $c$ " indicate the study area for the south coast survey. Numerals indicate the codes of survey plots. 
boulder beach, sand beach, and sand-mud flat.

The distribution of selected animal species was surveyed around the entire coast of the island on May 9, 1993. Eighty species were selected because of their large size and ease of identification in the field. Six members of a survey team participated and each of them searched for 10-15 of the 80 species. They evaluated the maximum density $\left(\right.$ no. $\left./ \mathrm{m}^{2}\right)$ of each species within each of the 43 survey plots shown in Fig. $1 \mathrm{~b}$ and recorded it as one of the following five classes: none (0), r (1-9), + (10-99), c (100-999) and $\mathrm{cc}(>1000)$.

The abundance of each species was compared between the sheltered area (east and south coasts: Plots 1-25 in Fig. 1b) and the exposed area (west and north coasts: Plots 26-43) of the island. The significance of differences was assessed by the Mann-Whitney $U$-test, based on the number of plots in which each density class $(0, r,+, c$, or cc) was recorded. Species significantly more abundant $(P<0.05)$ in Plots $1-25$ were classified as having a 'sheltered-coast distribution', and species significantly more abundant in Plots 26-43 as having an 'exposed-coast distribution'. Species found in more than half of all the 43 plots $(>22)$ and showing no significant difference between the two areas were classified as having an 'entire-coast distribution'. The abundance of each species was compared among the boulder-shore plots (Plots 1922, 36-38 in Fig. 1b), the sandy-shore plots (Plots 10,12,13,16,18), and the rocky-shore plots (the other Plots) by the Mann-Whitney $U$ test, based on the number of plots in which each density class was recorded. Species limited to the rocky-shore plots, or significantly more abundant $(P<0.05)$ there than in either the boulder-shore plots or the sandy-shore plots, were classified as having a 'rocky-shore distribution'. Species with a 'boulder-shore distribution' or a 'sandy-shore distribution' were determined in the same way.

\section{South coast survey}

The rocky-shore fauna and flora were investigated in a selected area of the south coast of the island on May 8, 1993. The area extended ca. $300 \mathrm{~m}$ along the coastline, and the rocky substratum within it was divided into 16 survey plots (Fig. 1c). Of these, only Plot 1 faced open water and was more exposed to wave action than the others. Four survey teams of two to four members each investigated the following four taxonomic groups: molluscs, crustaceans, other animals, and algae. They recorded all species of the four groups found in each plot. During the survey, photographs were taken at the same points where they had been taken in previous investigations, and compared with the earlier photographs.

\section{Comparison with previous data}

The results of the entire-coast survey in 1993 were compared with those obtained in 1983. In 1983, 56 animal species had been sought in 31 rocky-shore plots, and 45 species in 12 boulderor sandy-shore plots (Ohgaki et al., 1985). The abundance of each species was assessed qualitatively as 'none', 'rare', 'common', or 'abundant'. Fifty-five of the same rocky shore species were investigated again in 1993, and the abundance of each of the 55 in 1983 was compared between the sheltered area (east and south coasts: Plots 1-9, 11, 14, 15, 17, 23-25 in Fig. 1b) and the exposed area (west and north coasts: Plots 26-35, 39-43). The significance of differences was assessed by the Mann-Whitney $U$-test, and each species was classified as having 'sheltered-coast distribution', 'exposedshore distribution', or 'entire-coast distribution' as before. Twenty-one species showed one or another of these three distribution patterns in both 1983 and 1993, and for each such species the distribution pattern was compared between the two years. With the 55 species investigated in both 1983 and 1993, the number of rocky plots where each species occurred was counted. The sum of the numbers for all the species (the 'cumulative number of plots') was calculated and the values were compared between the two years.

The results of the south-coast survey in 1993 were compared with those in 1969 and 1984 obtained by the same methods. The total number of species, the number of plots in which each species was found, and the cumulative number of plots of all the species were compared among the three years. The geographical distributions of the recorded species were 
determined from the literature (Higo \& Goto 1993; Nishimura 1992, 1995), and those with a range on the Pacific coast of Japan limited to points south of the Boso Peninsula $\left(35^{\circ} \mathrm{N}\right)$, where the warm Kuroshio Current predominates, were defined as 'species with a southern geographical distribution'. The percentage of these species among all the species whose geographical ranges are known was calculated, both for the number of species and for the cumulative number of plots. The species empirically known to be abundant in nutrient-rich waters (Nishimura \& Suzuki 1971; Yoshida 1983) were termed 'indicator species of eutrophic water', and those abundant in nutrient-poor waters were called 'indicator species of oligotrophic water'. The numbers of plots where these species occurred were counted for the three years. The above comparisons were made mostly for animals, as the participants' ability to identify species was more consistent for animals than for plants.

\section{Environmental factors}

The biotic data obtained were analyzed in relation to several environmental factors: air and water temperatures, dissolved oxygen content, and water transparency. The monthly mean air temperature at Shirahama (Fig. 1a) was obtained from 'The Monthly Weather Report of Wakayama' (Wakayama Local Meteorological Observatory, 1969-1993). Monthly mean water temperature was calculated from the nearshore surface-water temperature measured daily at the mouth of Tanabe Bay (Fig. 1a; oceanographical data of the Seto Marine Biological Laboratory of Kyoto University, 19581994). The lowest values of the monthly mean air and water temperatures of each year were used for analysis. Dissolved oxygen content in the bottom water layer and water transparency were taken from Fuse (1989); the means of the values from a point east of Hatakejima Is. in summer (July and August) were used. The relation between time (years) and environmental factors (yearly mean values of the air and water temperatures, dissolved oxygen, and water transparency) were examined by rank correlation analysis (Kendall's $\tau$ ) for the periods from 1969 to 1983 and from 1984 to 1993, and increasing or decreasing trends in these environmental variables were identified.

\section{RESULTS}

\section{Entire coast survey in 1993}

In the survey of 80 selected animal species around the entire coast of Hatakejima Island in 1993, 60 species were recorded in the 43 survey plots (Appendix 1). Table 1 shows the patterns of species distribution on differently exposed coasts. Four species were significantly more abundant in the sheltered area than in the exposed area ("sheltered-coast distribution") , 17 were significantly more abundant in the exposed area than in the sheltered area (" exposed-coast distribution"), and 10 showed no significant difference between the two areas ("entire-coast distribution").

Table 2 shows the patterns of species distribution among different kinds of substratum. Twenty-two species were found only, or significantly most abundantly, on rocky shores (" rocky-shore distribution"), 6 were on boulder shores ("boulder-shore distribution"), and 4 were on sandy shores (" sandy-shore distribution").

\section{South coast survey in 1993}

In the survey of the fauna and flora of south coast research area, 112 species of animals and 61 of plants (total of 173 species) were recorded in the 16 survey plots (Appendix 1, Table 3). Among the animals, Mollusca formed the largest proportion both in terms of number of species (45\%) and cumulative number of plots (56\%), and Arthropoda (all were Crustacea) were the next largest. Among the plants, Rhodophyta formed the largest proportion in terms of number of species (54\%) and cumulative number of plots (60\%). Among the animals, species with a southern distribution ( $<$ $\left.35^{\circ} \mathrm{N}\right)$ formed $38 \%(33 / 86)$ of the total number of species and $21 \%(91 / 434)$ of the cumulative number of plots. 
Table 1. List of the species showing different patterns in distribution among the differently exposed coasts of Hatakejima Island in 1993. In the rows labeled "sheltered-coast distribution", asterisks indicate that the species was significantly more abundant in the sheltered area of the island than in the exposed area, and in the rows labeled "exposed-coast distribution", that the species was significantly more abundant in the exposed area than in the sheltered area $\left({ }^{*} 0.01<P<0.05\right.$; * $P<0.01$; Mann-Whitney $U$-test). In the rows labeled "entire-coast distribution", the species occurring in more than half the survey plots and yet showing no significant difference in abundance between the two areas $(P>0.05)$ are listed. For further details, see 'Methods'.

\begin{tabular}{|c|c|}
\hline $\begin{array}{l}\text { Sheltered-coast } \\
\text { distribution }\end{array}$ & $\begin{array}{l}\text { [Bryozoa] Zoobotryon pellucidum }\left({ }^{*}\right) \text { [Arthropoda] Balanus amphitrite }\left({ }^{*}\right) \text {, } \\
\text { B. albicostatus }\left({ }^{* *}\right), \text { [Mollusca] Batillaria cumingii }\left({ }^{*}\right)\end{array}$ \\
\hline $\begin{array}{l}\text { Exposed-coast } \\
\text { distribution }\end{array}$ & 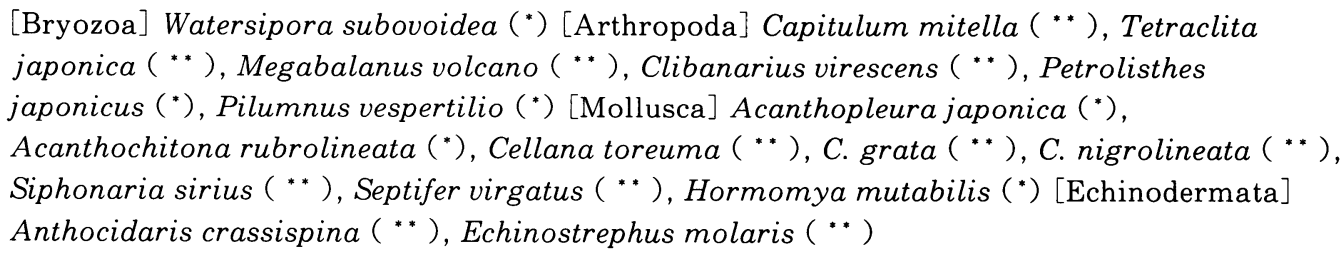 \\
\hline $\begin{array}{l}\text { Entire-coast } \\
\text { distribution }\end{array}$ & $\begin{array}{l}\text { [Cnidaria] Anthopleura japonica [Annelida] Pomatoleios kraussi [Arthropoda] Chthamalus } \\
\text { challengeri, Pagurus filholi, Nanosesarma gordoni [Mollusca] Patelloida saccharina lanx } \\
\text { Monodonta labio confusa, Nodilittorina radiata, Siphonaria japonica, Crassostrea gigas }\end{array}$ \\
\hline
\end{tabular}

Table 2. List of the species related to particular kinds of substratum on Hatakejima Island in 1993. In the rows labeled "rocky-shore distribution", the asterisks in parentheses show that the species was significantly more abundant in the rocky shore plots than in the boulder shore plots (the first asterisk[s]) and the sandy shore plots (the second asterisk[s]; * $0.01<P<0.05 ;{ }^{*} P<0.01$; Mann-Whitney $U$-test). The asterisks in the rows labeled "boulder-shore distribution" show that the species was significantly more abundant on boulder shores than on the other two kinds of substratum, and those in the rows labeled "sandy-shore distribution" show that the species was more abundant on sandy shores than on the other two kinds of substratum. "lm" means that the species was limited to the particular substratum. See 'Methods' for further details.

Rocky-shore distribution
[Cnidaria] Actinia equina ( $\mathrm{lm})$, Haliplanella lineata ( $\mathrm{lm}$ ) [Bryozoa] Zoobotryon pellucidum ( $\mathrm{lm})$, Watersipora subovoidea ( ** , **) [Arthropoda] Chthamalus challengeri ( ** , **), Tetraclita japonica $\left({ }^{*},{ }^{*}\right)$, Megabalanus volcano $(\mathrm{lm})$, Capitulum mitella $(\mathrm{lm})$ [Mollusca] Nodilittorina trochoides ( $\mathrm{lm})$, Serpulorbis imbricatus $(\mathrm{lm})$, Patelloida saccharina lanx ( * , ), Cellana grata $(\mathrm{lm})$, C. nigrolineata $\left({ }^{*},{ }^{*}\right)$, C. toreuma $(\cdots, \cdots)$, Siphonaria japonica (** , *), Crassostrea gigas (*, **), Xenostrobus atrata ( ** , ), Hormomya mutabilis ( ** , **), Mytilus galloprovincialis $\left(*,{ }^{*}\right)$, Acanthopleura japonica $(\cdots, \cdots)$ [Echinodermata] Echinostrephus moralis $(\mathrm{lm})$ [Protochordata] Styela plicata $(\mathrm{lm})$

Boulder-shore [Annelida] Eunice aphroditois (1m) [Arthropoda] Etisus laevimanus ( $\operatorname{lm}$ ), Gaetice distribution depressus ( $\cdots, \cdots)$, [Echinodermata] Asterina coronata japonica ( $\mathrm{lm})$, Holothulia paldalis (Im), Afrocucumis africana $(\mathrm{lm})$

Sandy-shore distribution
[Arthropoda] Pagurus dubius (1m), Scopimera globosa (lm) [Mollusca] Batillaria cumingii (*,") [Hemichordata] Balanoglossus carnosus (1m) 
Table 3. Number of species and the cumulative number of plots where they occurred (see 'Methods' for definition) for different taxonomic groups on the south coast of Hatakejima Island in 1993. Numerals in parentheses indicate the percentages among the total species.

\begin{tabular}{|c|c|c|}
\hline & No. species (\%) & Cumulative no. plots (\%) \\
\hline \multicolumn{3}{|l|}{ Animals } \\
\hline Porifera & $4 \quad(3)$ & $39 \quad(7)$ \\
\hline Cnidaria & $10 \quad(9)$ & $41 \quad(7)$ \\
\hline Platyhelminthes & 1 (1) & $1(-)$ \\
\hline Sipuncula & 1 ( 1$)$ & 3 ( 1$)$ \\
\hline Annelida & $9 \quad(8)$ & $30 \quad(5)$ \\
\hline Arthropoda & $30(27)$ & $130(23)$ \\
\hline Mollusca & $50(45)$ & $313(56)$ \\
\hline Echinodermata & $5 \quad(4)$ & $6(1)$ \\
\hline Protochordata & 2 (2) & $2(-)$ \\
\hline Total & $112(100)$ & $565(100)$ \\
\hline \multicolumn{3}{|l|}{ Plants } \\
\hline Cyanophyta & 2 ( 1$)$ & $2(1)$ \\
\hline Chlorophyta & $14(23)$ & $66 \quad(27)$ \\
\hline Phaeophyta & $12(20)$ & $31 \quad(12)$ \\
\hline Rhodophyta & $33(54)$ & $147 \quad(60)$ \\
\hline Total & $61(100)$ & $246(100)$ \\
\hline
\end{tabular}

\section{Comparison with previous data: Entire coast survey}

The distribution of selected intertidal animals around the entire coast of the island was compared between 1983 (Ohgaki et al., 1985) and 1993 (present study). For the 55 species censused on the rocky shores in both years, the cumulative number of plots was 570 in 1983 and 585 in 1993. Thirteen species increased and 13 decreased by five plots or more between 1983 and 1993. Of the 13 species that increased, the following five increased by 10 plots or more: Hemigrapsus sanguineus, Cellana toreuma, Monodonta labio confusa, Siphonaria sirius, and Hormomya mutabilis. Of the 13 species that decreased, the following three decreased by 10 plots or more: Acanthopleura japonica, Capitulum mitella, and Mytilus galloprovincialis.

The patterns of species distribution among differently exposed coasts were compared between 1983 and 1993 (Table 4). Of the 21 species that showed clear distribution patterns among

Table 4. Distribution patterns of 21 intertidal animal species in relation to wave exposure on Hatakejima island in 1983 and 1993 (see 'Methods' and Table 2 for each distribution pattern). Sh.: sheltered-coast distribution. Ex.: exposed-coast distribution. En.: entire-coast distribution. The numerals are numbers of species. For example, the numeral " 3 " in the first row and the first column means that three species showed a "sheltered-coast distribution" in both 1983 and 1993.

\begin{tabular}{lrrrr}
\hline & \multicolumn{2}{c}{ 1993 } & \\
& Sh. & Ex. & En. & Total \\
\hline Sheltered-coast distribution & 3 & 0 & 0 & 3 \\
Exposed-coast distribution & 0 & 9 & 2 & 11 \\
Entire-coast distribution & 0 & 2 & 5 & 7 \\
Total & 3 & 11 & 7 & 21 \\
\hline
\end{tabular}



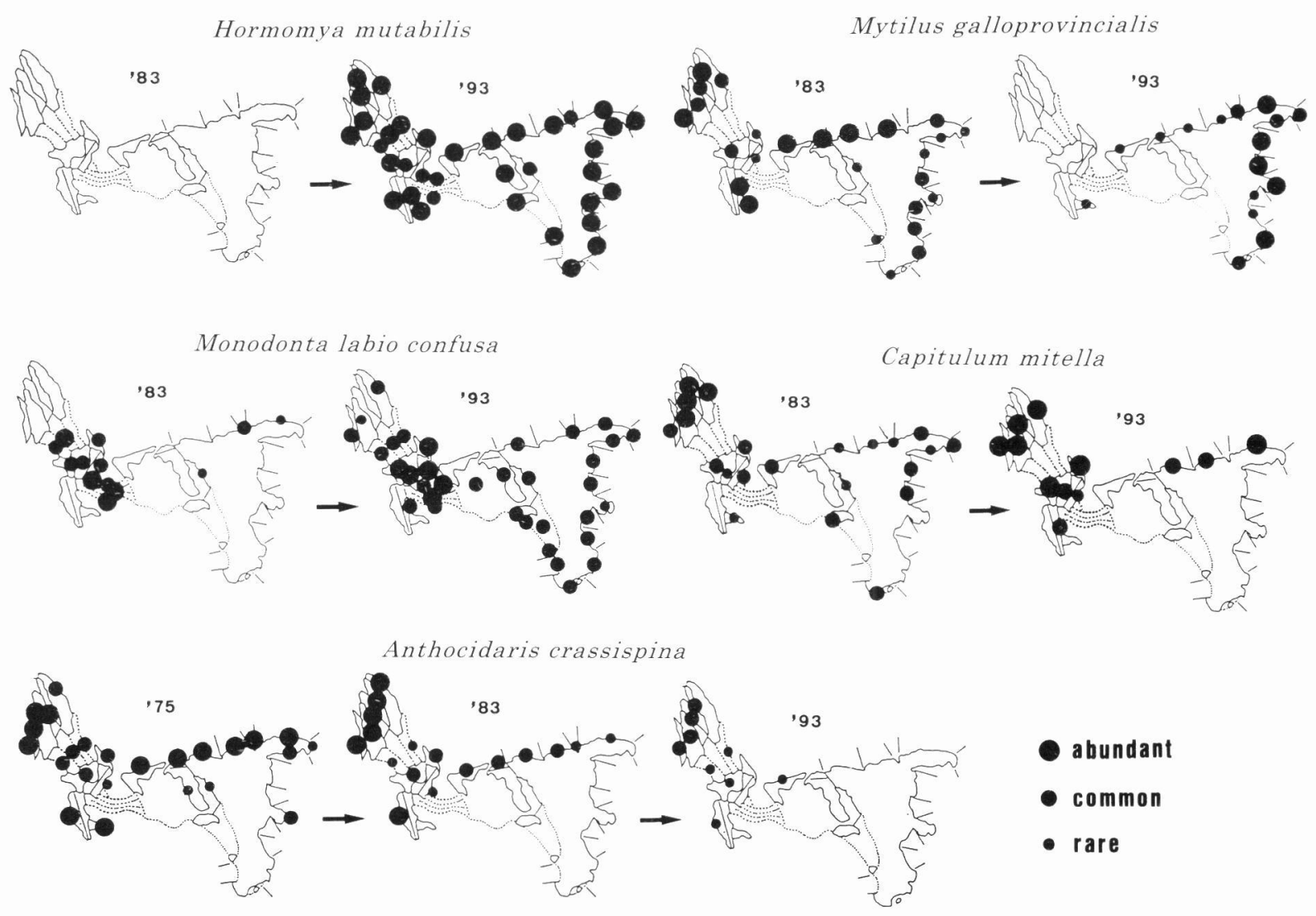

Fig. 2. Examples of distributional changes in intertidal animal species on Hatakejima Island. The circle sizes for 1993 have a quantitative basis (see 'Methods') but those for 1975 and 1983 represent relative abundances. Mytilus galloprovincialis and Capitulum mitella were not sought on the boulder and sandy shores in 1983.

differently exposed coasts in both years, two species (Chthamalus challengeri and Patelloida saccharina lanx) changed from the exposedcoast to the entire-coast distribution, and another two (Watersipora subovoidea and Clibanarius virescens) changed from the entirecoast to the exposed-coast distribution. But 17 of the 21 species did not show significant temporal change between the two years.

Fig. 2 shows some examples of the temporal change in species distribution. Hormomya mutabilis was not found in 1983 but occurred around the whole island in 1993. Mytilus galloprovincialis was found widely around the island in 1983 but disappeared from the western coast in 1993. Monodonta labio confusa was almost limited to the western boulder beach in 1983, but extended to the eastern and the western rocky shores in 1993. Capitulum mitella was found around the whole island in 1983, but only on the relatively exposed west and north coasts in 1993. Anthocidaris crassispina was recorded widely around the island in 1975, being less abundant on the east and south coasts than on the west and north coasts (Takahata et al., 1984). It was limited to the latter areas in 1983 and its frequency of occurrence was reduced even there by 1993, showing a continuing retreat to the exposed area.

Comparison with previous data: South coast survey

The intertidal fauna and flora in the south coast research area in 1993 were compared with those in 1969 and 1984 (Ohgaki 1984). The number of species of animals was 101 in 1969, 97 in 1984, and 112 in 1993. The cumulative number of 
plots occupied by all the animal species was 626 in 1969, 507 in 1984, and 565 in 1993. Thus, both the number of species and the cumulative number of plots decreased from 1969 to 1984 and increased from 1984 to 1993.

Table 5 summarizes the number of species that showed or did not show marked changes in distribution range (no. of plots) during 19691984 and 1984-1993. From 1969 to 1984, nine species obviously increased in number of plots and 22 species decreased, the number of decreasing species being larger. From 1984 to 1993, 10 species increased in number of plots and seven species decreased, the number of increasing species being larger. Of the 22 species that decreased from 1969 to 1984, 16 showed no marked recovery from 1984 to 1993 . In particular, the following eight molluscan species occurred in more than half of the plots in 1969 but in none in 1984 or 1993: Nerita albicilla, Nerita japonica, Clypeomorus humilis, Planaxis sulcatus, Cronia margariticola, Cronia fusca [gastropods], Septifer bilocularis, and Saccostrea kegaki [bivalves]. Of all 136 species examined, only one, Crassostrea gigas, increased both from 1969 to 1984 and from 1984 to 1993. Hormomya mutabilis was found in only one plot in both 1969 and 1983, but in 13 of the 16 plots in 1993.

Fig. 3 shows the scenic changes at two sites on the south coast from 1969 to 1993. In 1969, an oyster (Saccostrea kegaki) was attached densely to the bare, dark-colored rock surface.

Table 5. The number of animal species that showed or did not show marked changes in the number of plots where they occurred on the south coast of Hatakejima Island, from 1969 to 1984 and from 1984 to 1993 . $\uparrow:$ increase by $\geqq 5$ plots out of 16 in all. $\downarrow$ : decrease by $\geqq 5$ plots. $\rightarrow$ : change by $<5$ plots or no change. The numerals are numbers of species. For example, the numeral " 1 " in the first row and the first column means that one species increased by $\geqq 5$ plots both from 1969 to 1984 and from 1984 to 1993.

\begin{tabular}{|c|c|c|c|c|c|}
\hline & \multicolumn{4}{|c|}{ '84-'93 } \\
\hline & & $\uparrow$ & $\rightarrow$ & $\downarrow$ & Total \\
\hline \multirow{4}{*}{ '69-'84 } & $\uparrow$ & 1 & 5 & 3 & 9 \\
\hline & $\rightarrow$ & 3 & 98 & 4 & 105 \\
\hline & $\downarrow$ & 6 & 16 & 0 & 22 \\
\hline & tal & 10 & 119 & 7 & 136 \\
\hline
\end{tabular}

In 1983, sedimentation was obvious: the rock surface was covered with filamentous bluegreen algae trapping silt and detritus, and no oysters were found (Ohgaki 1989). In 1993, the bare rock surface again appeared and another oyster species, Crassostrea gigas, was attached sparsely on it. The dark splotches on the rock platform in "a-3" are aggregations of a mussel (Hormomya mutabilis), which were not seen in 1969. Such photographic evidence of the alternation of sessile bivalves is consistent with distributional changes in these species mentioned above.

\section{Environmental factors and biotic changes}

Table 6 (upper half) shows the temporal changes in some environmental factors in the Tanabe Bay area. The air and the water temperatures significantly decreased from 1969 to 1984 and significantly increased from 1984 to 1993. The number of days with water temperature lower than $11^{\circ} \mathrm{C}$ (the level below which the tropical and subtropical marine species in Tanabe Bay are empirically known to be damaged [Ohgaki 1989]) was also determined for the 5-yr period preceding each survey: one during 1965-69, 45 during 1980-84, and seven during 1989-93. These indicate colder winter conditions in the early 1980s than before and afterwards. The oxygen saturation in the bottom water layer and water transparency, useful indicators of eutrophication (Yoshida 1983), decreased from 1969 to 1984, the change in water transparency being significant. Records of these indices obtained by the same methods as before are not available after 1984, but it has been reported that the dissolved oxygen near the bottom in summer (August) increased and the frequency of plankton blooms decreased in Tanabe Bay until 1993 (Takeuchi 1994).

Concerning the species with a southern distribution $\left(<35^{\circ} \mathrm{N}\right)$ on the south coast, the number of species and the cumulative number of plots, as percentages of the values for all the animal species, decreased from 1969 to 1984 and increased from 1984 to 1993 , only the change in the latter percentage from 1969 to 1984 being significant (Table 6). The mean number of plots per species of the species with a southern distribution significantly decreased from 1969 to 


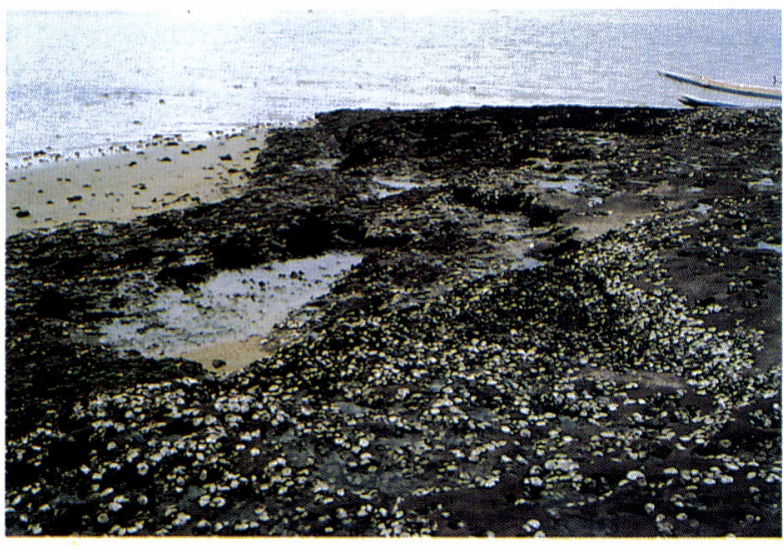

$\mathrm{a}-1$

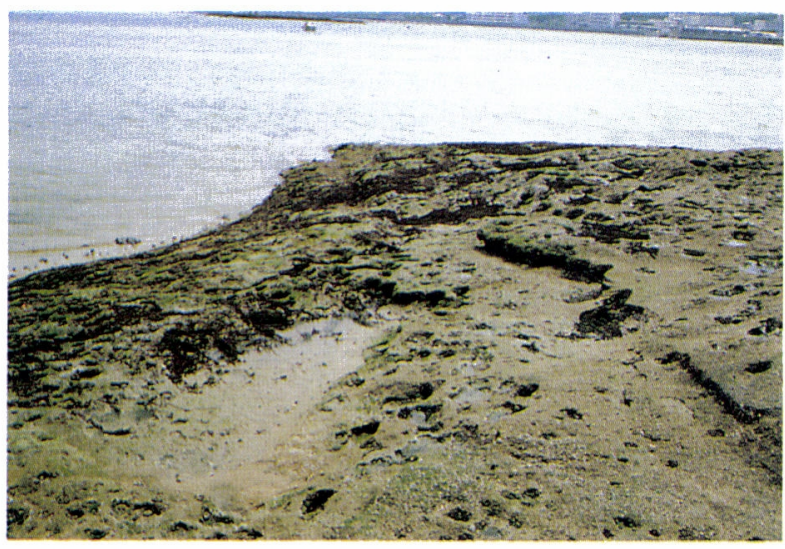

$\mathrm{a}-2$

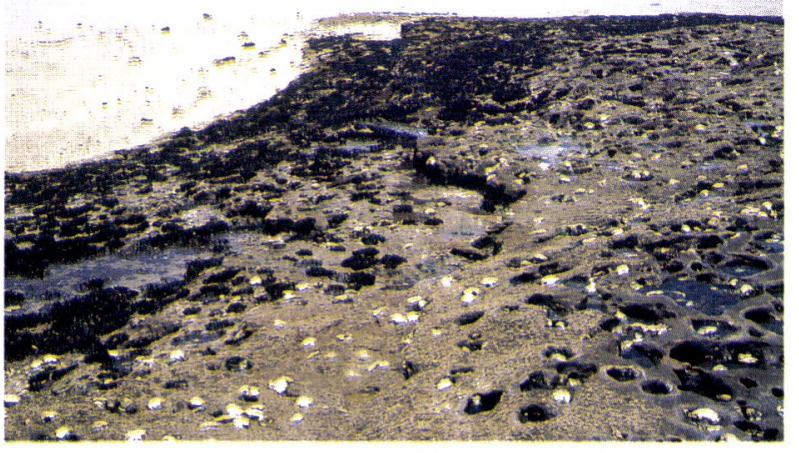

$\mathrm{a}-3$

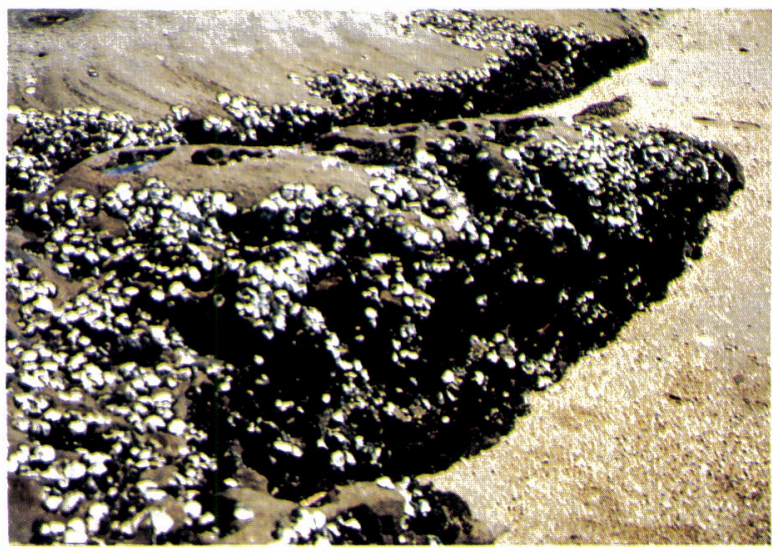

$b-1$

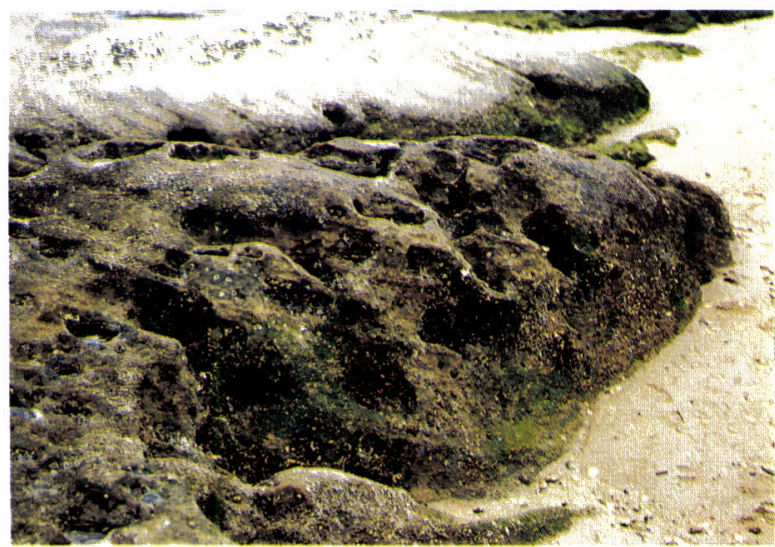

$b-2$

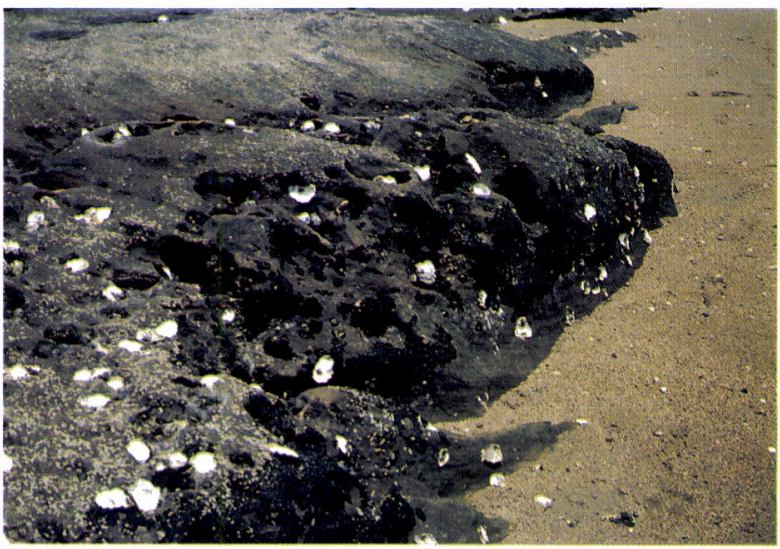

$b-3$

Fig. 3. Scenic changes on the south coast of Hatakejima Island. Photographs "a-1,2,3" were taken in Plot 5, and "b-1,2,3" in Plot 4 (Fig. 1c). The dates of the photographs are March 1969 for "a-1" and "b-1" (courtesy of Dr. T. Tokioka), 15 May 1984 for "a-2" and "b-2", and 3 May 1984 for "a-3" and "b-3". 
Table 6. Changes in environmental conditions in Tanabe Bay and in the abundance of species with a southern geographical distribution $\left(<35^{\circ} \mathrm{N}\right)$ on the south coast of Hatakejima Island during 1969-1984 and 1984-1993. Numerals outside the parentheses in the upper rows are the coefficients of rank correlation (Kendall's $\tau$ ) between time (years) and the environmental factors, and those in the parentheses the number of years examined. Upward and downward arrows indicate increasing and decreasing trends, respectively. Significance of differences for "\% no. species" and "\% cumulative no. plots" of the species with a southern geographical distribution was examined by Chisquare tests, and for "no. plots / species" by a $t$-test ( $" P<0.01 ; \cdot 0.01<P<0.05 ;$ NS, $P>0.05)$. AT; air temperature; WT, water temperature; Bottom $\mathrm{O}_{2}$, dissolved oxygen content near bottom.

\begin{tabular}{|c|c|c|}
\hline & $1969 \rightarrow 1984$ & $1984 \rightarrow 1993$ \\
\hline \multicolumn{3}{|l|}{ Environmental factors } \\
\hline Lowest AT & $-0.33(16) \downarrow *$ & $0.51(10) \uparrow *$ \\
\hline Lowest WT & $-0.58(16) \downarrow * *$ & $0.44(10) \uparrow^{*}$ \\
\hline Bottom $\mathrm{O}_{2}$ & $-0.13(16) \downarrow N S$ & - \\
\hline Water transparency & $-0.57(16) \downarrow^{* *}$ & - \\
\hline \multicolumn{3}{|c|}{$\begin{array}{l}\text { Species with a southern geographical distribution } \\
\text { (the south coast, animals) }\end{array}$} \\
\hline$\%$ no. species & $41 \rightarrow 33 \quad \downarrow N S$ & $33 \rightarrow 38 \uparrow \mathrm{NS}$ \\
\hline$\%$ cumulative no. plots & $53 \rightarrow 18 \downarrow \cdots$ & $18 \rightarrow 21 \uparrow \mathrm{NS}$ \\
\hline No. plots/species & $5.8 \rightarrow 2.7 \downarrow *$ & $2.7 \rightarrow 2.7 \mathrm{NS}$ \\
\hline
\end{tabular}

1984, but did not differ between 1984 and 1993.

Concerning the indicator species of eutrophic water and those of oligotrophic water, most of the former increased their number of occupied plots from 1969 to 1984, while the latter species
Saccostrea kegaki decreased drastically on the south coast (Table 7). From 1983-84 to 1993 the changes on the south coast were not clear, but several indicator species of eutrophic water decreased around the entire coast. Their increase

Table 7. Increase and decrease in the number of plots where indicator species of eutrophic or oligotrophic waters (Nishimura \& Suzuki 1971; Yoshida 1983) occurred on the rocky shores of Hatakejima Island. The significance of changes in the mean number of plots occupied by the indicator species of eutrophic water was examined by $t$-tests ( ** $P<0.01 ; \mathrm{NS}, P>0.05)$.

\begin{tabular}{|c|c|c|c|}
\hline \multirow[b]{3}{*}{ Indicator species } & \multicolumn{3}{|c|}{ Change in no. plots } \\
\hline & \multicolumn{2}{|c|}{ South coast } & \multirow{2}{*}{$\begin{array}{c}\text { Entire coast } \\
{ }^{\prime} 83 \rightarrow{ }^{\prime} 93\end{array}$} \\
\hline & $' 69 \rightarrow$ '84 & $' 84 \rightarrow$ '93 & \\
\hline \multicolumn{4}{|l|}{ Oligotrophic water } \\
\hline Saccostrea kegaki & -15 & 0 & \\
\hline Megabalanus volcano & +1 & 0 & -5 \\
\hline \multicolumn{4}{|l|}{ Eutrophic water } \\
\hline Cirriformia tentaculata & +5 & -3 & \\
\hline Balanus amphitrite & 0 & -1 & -5 \\
\hline Balanus albicostatus & +7 & +4 & -3 \\
\hline Mytilus galloprovincialis & +2 & -2 & -10 \\
\hline Crassostrea gigas & +6 & +9 & \\
\hline Styela plicata & +1 & -1 & -7 \\
\hline Ulva pertusa & +6 & -4 & \\
\hline Mean $\pm \mathrm{SE}$ & $+3.9 \pm 1.0^{* *}$ & $+0.3 \pm 1.6 \mathrm{NS}$ & $-6.3 \pm 1.3^{* *}$ \\
\hline
\end{tabular}


in the mean number of plots on the south coast from 1969 to 1984 and the decrease around the entire coast from 1983 to 1993 were statistically significant.

\section{DISCUSSION}

Ohgaki (1989) reviewed changes in the intertidal fauna in Tanabe Bay, including Hatakejima Island, for ca. 30 years until the 1980 s. He detected a decrease in density of several animal species and in species richness of molluscs and echinoderms, and pointed out that the observed faunal changes occurred in parallel with an increase in organic pollution and a decrease in water temperature. In the present study, we examined more quantitative data, and also more recent data, and explored the relationship between the biotic changes and environmental factors.

The total number of animal species and the cumulative number of plots occupied by them on the south coast of Hatakejima Island decreased from 1969 to 1984 and increased from 1984 to 1993 . From 1969 to 1984 , the number of species with a markedly reduced number of occupied plots exceeded that of species with an obvious increase, but vice versa from 1984 to 1993 (Table 5). These results suggest that the species richness and distribution ranges of animals were reduced from 1969 to 1984 and recovered from 1984 to 1993 on the south coast. As the cumulative number of plots in 1993 was less than in 1969, and several species widely distributed in 1969 were not found at all in 1984 and 1993, the recovery from 1984 to 1993 was evidently not enough to regain the earlier faunal richness. Similarly Hattori (1993) detected a decrease in the number of 'common' species in the subtidal fish communities in Tanabe Bay from the 1970 s to the 1980 s and an increase from the 1980 s to the 1990 s.

Between 1969 and 1984, when the air and water temperatures were falling significantly, the species with a southern geographical distribution $\left(<35^{\circ} \mathrm{N}\right)$ showed significant decreases in the percentage of cumulative number of plots which they occupied and in the mean number of plots occupied on the south coast of the island (Table 6). From 1984 to 1993, these species tended to increase in terms of percentage of number of species and cumulative number of plots, although the changes were not significant. During this period, the air and water temperatures were rising significantly, but the level of significance for the water temperature was lower than that between 1969 and 1984. Thus, both the abundance of the species with a southern distribution and the temperature conditions changed generally in parallel during both time intervals, although such changes were less obvious in the latter period. In the Tanabe Bay area, cold winters have often damaged the tropical and subtropical marine species (Tokioka 1963; Araga \& Tanase 1968; Kuwamura \& Kashiyama 1976). As the southern species comprise a large part of the island's intertidal fauna, i.e. $38 \%$ on the south coast (present study) and $52 \%$ around the entire coast (Ohgaki 1989), the parallel changes mentioned above imply a substantial effect of temperature on the island's shore fauna.

Indicator species of eutrophic water significantly increased from 1969 to 1984 in terms of number of plots occupied on the south coast, and they decreased from 1983 to 1993 around the entire coast of the island (Table 7). The analysis of environmental factors detected a non-significant decrease in dissolved oxygen near the bottom and a significant decrease in water transparency from 1969 to 1984 (Table 6 ). The dissolved oxygen content increased and the frequency of plankton blooms decreased from 1984 to 1993 (Takeuchi 1994). As nearbottom dissolved oxygen, water transparency, and frequency of plankton blooms are useful indicators of eutrophication (Yoshida 1983), the observed fluctuations in these factors suggest that the nutrient level in the inner part of Tanabe Bay increased before, and decreased after, the mid-1980s. As the abundance of indicator species of eutrophic water and the environmental factors related to nutrient level have been changing in parallel as shown above, it is likely that organic enrichment in Tanabe Bay has had some effect on the island's shore fauna.

The present study suggests that the temperature conditions and nutrient level have affected the fluctuations in the shore fauna of Hatakejima Island over the last 25 years. 
Further studies are necessary to determine the detailed function of these environmental variables and the possibility of the existence of other factors.

Acknowledgments. We thank Naoya Abe (Osaka International Women's College), Hiroyuki Ariyama (Osaka Prefectural Fisheries Experimental Station), Minako Hanaoka (Kyoto University), Keiji Iwasaki (Nara University), Koichi Takenouchi (Nara-gakuen High School), Hidetomo Tanase and Shigeyuki Yamato (Seto Marine Biological Laboratory, Kyoto University), and Takashi Hanai who participated in the research in 1993. The authors are grateful to the members of 'The Argonauts' (Kyoto Marine Biological Seminar) for their useful discussion on the data of this study, to Naoya Abe for his comments on the draft and to Taiji Kurozumi (Natural History Museum and Institute, Chiba) for taxonomic advice.

\section{REFERENCES}

Araga, C. and H. Tanase 1968 Further record of winter fish stranding in the vicinity of Seto. Publications of the Seto Marine Biological Laboratory, 16: 207-218.

Dahl, A. L. and A. E. Lamberts 1977 Environmental impact on a Samoan coral reef: a resurvey of Mayor's 1917 transect. Pacific Science, 31: 309-319.

Davis, G. E. 1982 A century of natural change in coral distribution at the Dry Tortugas: a comparison of reef maps from 1881 and 1976. Bulletin of Marine Science, 32: 608-623.

Done, T. 1992 Constancy and change in some Great Barrier Reef coral communities: 1980-1990. American Zoologist, 32: 655-662.

Fuse, S. 1989 Progressive changes of oceanographic conditions in Tanabe Bay. Annual Report of the Seto Marine Biological Laboratory, 3: 35-46 (in Japanese).

Hattori, A. 1993 Long-term changes of a fish fauna at a rocky reef of Tanabe Bay, Wakayama. Contribution from Kansai Organization for Nature Conservation, 15: 25-45 (in Japanese).

Higo, S. and Y. Goto 1993 A Systematic List of Molluscan Shells from the Japanese Is. and the Adjacent Area. Elle Scientific Publications, Osaka, 693pp. (in Japanese).
Josefson, A. B. 1990 Increase of benthic biomass in the Skagerrak-Kattegat during the 1970s and 1980s - effects of organic enrichment? Marine Ecology Progress Series, 66: 117-130.

Kuwamura, T. and Y. Kashiyama 1976 Massive destruction of cowries (Mollusca, Cypraeidae) due to low temperature of the sea water in the vicinity of Shirahama, Japan. Nankiseibutu, 18: 46-48 (in Japanese).

Nishimura, S. (ed.) 1992 Guide to Seashore Animals of Japan with Color Pictures and Keys, Vol. I . Hoikusha Publication Co. Ltd., Osaka, 425pp. (in Japanese).

Nishimura, S. (ed.) 1995 Guide to Seashore Animals of Japan with Color Pictures and Keys, Vol. II . Hoikusha Publication Co. Ltd., Osaka, 663pp. (in Japanese).

Nishimura S. and K. Suzuki 1971 Illustrated Catalogue of Japanese Seashore Animals. Hoikusha Publication Co. Ltd., Osaka, 196pp. (in Japanese).

Ohgaki, S. 1984 Intertidal fauna and flora on the west coast of Hatakejima Island in 1969 and 1984. Nankiseibutu, 26: 77-85 (in Japanese).

Ohgaki, S. 1989 Long-term change in the coastal biota of Hatakejima Island. Japanese Journal of Ecology, 39: 27-36 (in Japanese with English synopsis).

Ohgaki, S., N. Abe, T. Takegami, and K. Wada 1985 Spatial occurrence of 91 intertidal animal species on Hatakejima Island, 1983. Publications of the Seto Marine Biological Laboratory, 30: 325-332.

Ohgaki, S. and H. Tanase 1987 Composition of the fixed sea urchin colony on Hatakejima Island, 1983-1987, with review of the past 25-years data. Publications of the Seto Marine Biological Laboratory, 32:335-337.

Pearse, J. S. and A. H. Hines 1987 Long-term population dynamics of sea urchins in a central California kelp forest: rare recruitment and rapid decline. $M a-$ rine Ecology Progress Series, 39: 275-283.

Pearson, T. H., A. B. Josefson, and R. Rosenburg 1985 Petersen's benthic stations revisited. I . Is the Kattegatt becoming eutrophic? Journal of Experimental Marine Biology and Ecology, 92: 157-206.

Takahata, Y., S. Kimura, H. Honjo, and A. Yamamoto 1984 Distribution of sea urchins around Hatakejima Island. Nankiseibutu, 26: 25-29 (in Japanese).

Takeuchi, T. 1994 Has the environment of Tanabe Bay recovered? Newsletter from the Wakayama Prefectural Fisheries Experimental Station, 168: 2-5 (in Japanese).

Tokioka, T. 1963 Supposed effects of the cold weather of the winter 1962-1963 upon the intertidal fauna in 
the vicinity of Seto. Publications of the Seto Marine Biological Laboratory, 11: 245-254.

Wilson, D. P. 1971 Sabellaria colonies at Duckpool, north Cornwall, 1961-1970. Journal of the Marine Biological Association of the United Kingdom, 51: 509-580.

Yoshida, Y. 1983 Methods using biological indices. In, Environmental Assessment for Coastal Fisheries, Yoshida, T. (ed.), Koseisha-koseikaku Co. Ltd., Tokyo, pp. 25-46 (in Japanese).

\section{Address \\ Shun-ichi Ohgaki (reprint request)}

Ryohei Yamanishi: Osaka Museum of Natural History, 1-23 Nagai-koen, Higashisumiyoshi, Osaka 546, Japan. Yasunobu Nabeshima: Osaka Prefectural Fisheries Experimental Station, 2926-1, Tanagawa-tanigawa, Misaki, Sen-nan, Osaka 599-03, Japan.

Keiji Wada: Department of Biological Science, Faculty of Science, Nara Women's University, Kitauoyanishimachi, Nara 630, Japan.

Appendix 1. List of 80 animal species specifically censused in the 43 survey plots around the entire coast of Hatakejima Island (Fig. 1b) in May, 1993. The numeral in parentheses indicates the number of plots where the species was found.

[CNIDARIA] Actinia equina (1), Haliplanella lineata (14), Anthopleura japonica (18), Oulastrea crispata (4) [BRYOZOA] Zoobotryon pellucidum (9), Watersipora subovoidea (21) [ANNELIDA] Eunice aphroditois (1), Pomatoleios kraussi (40) [ARTHROPODA] Capitulum mitella (12), Chthamalus challengeri (33), Tetraclita japonica (16), Balanus amphitrite (28), B. albicostatus (17), Megabalanus volcano (12), Clibanarius virescens (20), Pagurus filholi (30), P. dubius (1), Petrolisthes japonicus (18), Leptodius exaratus (17), Etisus laevimanus (1), Pilodius nigrocrinitus (2), Pilumnus vespertilio (10), Scopimera globosa (1), Hemigrapsus sanguineus (18), H. penicillatus (3), Gaetice depressus (17), Nanosesarma gordoni (21) [MOLLUSCA] Acanthopleura japonica (35), Acanthochitona rubrolineata (28), Cellana toreuma (32), C. grata (12), C. nigrolineata (25), Patelloida saccharina lanx (39), Monodonta labio confusa (35), Lunella coronata coreensis (16), Littorina brevicula (20), Nodilittorina radiata (24), N. trochoides (1), Serpulorbis imbricatus (1), Batillaria cumingii (12), Thais clavigera (6), Siphonaria japonica (31), S. acmaeoides (9), S. sirius (12), Xenostrobus atrata (19), Septifer virgatus (13), Mytilus galloprovincialis (16), Hormomya mutabilis (36), Crassostrea gigas (39) [ECHINODERMATA] Asterina coronata japonica (2), Diadema setosum (4), Hemicentrotus pulcherrimus (3), Echinostrephus molaris (7), Anthocidaris crassispina (9), Echinometra mathaei (3), Holothuria pardalis (1), Afrocucumis africana (2), Polycheira rufescens (5) [HEMICHORDATA] Balanoglossus carnosus (1) [PROTOCHORDATA] Styela plicata (2)

* Sought but not found:

[ANNELIDA] Chaetopterus variopedatus [ARTHROPODA] Euraphia pilsbryi, Ocypode stimpsoni, [MOLLUSCA] Diloma suavis, Nerita albicilla, N. japonica, Planaxis sulcatus, Clypeomorus bifasciata, Japeuthria ferrea, Saccostrea mordax, S. kegaki, Modiolus nipponicus [ECHINODERMATA] Asterina pectinifera, Coscinasterias acutispina, Pseudocentrotus depressus, Mespilia globulus, Tripneustes gratilla, Ophioplocus japonicus, Holothuria moebii, Holothuria leucospirota

$* *$ Change of scientific name; 1983 (Ohgaki et al. 1985) $\rightarrow 1993$ (present study):

[CNIDARIA] Haliplanella luciae $\rightarrow$ Haliplanella lineata [BRYOZOA] Dakaria subovoidea $\rightarrow$ Watersipora subovoidea [ARTHROPODA] Pollicipes mitella $\rightarrow$ Capitulum mitella, Balanus albicostatus albicostatus $\rightarrow$ Balanus albicostatus, Balanus amphitrite amphitrite $\rightarrow$ Balanus amphitrite, Balanus tintinnabulum volcano $\rightarrow$ Megabalanus volcano, Tetraclita squamosa japonica $\rightarrow$ Tetraclita japonica, Pagurus geminus $\rightarrow$ Pagurus filholi [MOLLUSCA] Liolophura japonica $\rightarrow$ Acanthopleura japonica, Patelloida saccharina $\rightarrow$ Patelloida saccharina lanx, Lunella coronata $\rightarrow$ Lunella coronata coreensis, Heminerita japonica $\rightarrow$ Nerita japonica, Nodilittorina exigua $\rightarrow$ Nodilittorina radiata, Nodilittorina pyramidalis $\rightarrow$ Nodilittorina trochoides, Clypeomorus humilis $\rightarrow$ Clypeomorus bifasciata, Adula atrata $\rightarrow$ Xenostrobus atrata, Mytilus edulis $\rightarrow$ Mytilus galloprovincialis, Modiolus auriculatus $\rightarrow$ Modiolus nipponicus [ECHINODERMATA] Echinostrephus aciculatus $\rightarrow$ Echinostrephus molaris 
Appendix 2. List of all the species found in 16 survey plots in the south coast survey area of Hatakejima Island (Fig. 1c) in May, 1993. The numeral in parentheses indicates the number of plots where the species was found.

[PORIFERA] Halichondria okadai (9), H. japonica (13), H. panicea (10), Haliclona permollis (7) [CNIDARIA] Anthopleura japonica (12), A. asiatica (1), A. fuscoviridis (1), A. aff. xanthoglammica (1), A. sp. (9), Haliplanella lineata (10), Dendronephthya gigantea (1), Oulastrea crispata (4), Dynamena crisioides (1), Sertulariidae gen. sp. (1) [PLATYHELMINTHES] Stylochus sp. (1) [SIPUNCULA] Phascolosoma sp. (3) [ANNELIDA] Perinereis cultrifera (5), Lepidonotus elongatus (4), Cirriformia tentaculata (3), Arabella iricolor (1), Pomatoleios kraussi (10), Hydroides ezoensis (2), Protohydroides sp. (2), Typosyllis sp. (1), Spirorbidae gen. sp. (1) [ARTHROPODA] Chthamalus challengeri (16), Tetraclita japonica (2), Balanus amphitrite (14), B. albicostatus (16), Megabalanus volcano (1), M. rosa (1), Talitridae gen. sp. (1), Ligia exotica (2), Palaemon pacificus (1), Alpheus brevicristatus (1), Clibanarius virescens (4), Pagurus filholi (15), P. dubius (9), Porcellanidae gen. sp. (1), Tiarinia cornigera (2), Leptodius exaratus (2), Pilodius nigrocrinitus (1), Eriphia smithi (2), Macromedaeus distinguendus (1), Cycloxanthops truncatus (1), Paraxanthias elegans (1), Actaea pulchella (1), Pilumnus vespertilio (1), Xanthidae gen. sp. (2), Pachygrapsus crassipes (2), Hemigrapsus sanguineus (9), H. penicillatus (3), Gaetice depressus (4), Nanosesarma gordoni (12), Plagusia dentipes (2) [MOLLUSCA] Placiphorella stimpsoni (1), Acanthopleura japonica (10), Acanthochitona rubrolineata (10), Cellana toreuma (9), C. grata (1), C. nigrolineata (7), Patelloida saccharina lanx (14), P. pygmaea (9), Collisella heroldi (13), C. langfordi (1), Nipponacmaea fuscoviridis (8), Monodonta labio confusa (14) Fossarina picta (1), Omphalius rusticus (3), Turbo stenogyrum (1), Lunella coronata coreensis (14), Littorina brevicula (14), Nodilittorina radiata (10), N. trochoides (1), Peasiella infracostata (15), Barleeia angustata (6), Serpulorbis imbricatus (1), Batillaria cumingii (13), Ravitrona caputserpentis (1), Ponda vitellus (1), Mauritia arabica (1), Thais clavigera (9), T. bronni (5), Morula musiva (1), M. granulata (1), Ergaratax contructus (4), Siphonaria japonica (16), S. acmaeoides (9), Haloa japonica (1), Aplysia kurodai (4), A. juliana (1), A. parvula (2), A. oculifera (2), Dolabella auricularia (1), Pleurobranchaea japonica (1), Dendrodoris arborescens (2), Barbatia virescens (8), Xenostrobus atrata (12), Mytilus galloprovincialis (5), Hormomya mutabilis (13), Pinctada fucata martensii (9), Anomia chinensis (1), Crassostrea gigas (15), Lasaea undulata (1), Claudiconcha japonica (11) [ECHINODERMATA] Diadema setosum (1), Hemicentrotus pulcherrimus (1), Echinostrephus molaris (1), Anthocidaris crassispina (2), Pseudocentrotus depressus (1) [PROTOCHORDATA] Styela plicata (1), S. canopus (1)

[CYANOPHYTA] Calothrix sp. (1), Phormidium sp. (1) [CHROROPHYTA] Collinsiella sp. (2), Monostroma nitidum (2), Ulva pertusa (2), U. conglobata (15), Enteromorpha compressa (5), E. intestinalis (10), Capsosiphon fulvescens (1), Cladophora conchopheria (12), C. sp. 1 (3), C. sp. 2 (1), Chaetomorpha crassa (2), Urospora sp. (10), Bryopsis plumosa (1), Codium sp. (1) [PHAEOPHYTA] Ectocarpus sp. (1), Dictyota dichotoma (1), Pachydictyon coriaceum (1), Dictyopteris prolifera (1), Padina arborescens (4), Colpomenia sinuosa (6), Undaria undarioides (1), Sargassum piluliferum (3), S. patens (1), S. thunbergii (10), S. hemiphyllum (1), Ralfsia verrucosa (1) [RHODOPHYTA] Porphyra suborbiculata (2), Dermonema pulvinatum (2), Gelidium divaricatum (15), G. pusillum (5), G. elegans (5), G. sp. (1), Pterocladia capillacea (8), P. nana (1), Lithophyllum okamurae (6), Amphiroa zonata (4), A. sp. (2), Corallina pilulifera (14), Titanoderma canescens (1), Jania sp. (4), Grateloupia filicina (11), G. imbricata (1), Pachymeniopsis lanceolata (1), Carpopeltis prolifera (1), Hypnea charoides (5), Caulacanthus usutulatus (15), Gracilaria bursa-pastoris (2), G. gigas (2), G. incurvata (3), Ahnfeltiopsis flabelliformis (1), Chondracanthus intermedius (11), Lomentaria hakodatensis (7), Champia parvula (2), Ceramium tenerrimum (8), Erythroglossum minimum (1), Acrosorium yendoi (1), Polysiphonia japonica (2), Laurencia majuscula (1), L. sp. (2), Symphyocladia marchantioides (1) 